INTRODUCTION TO THE MINUTES OF THE PROPRIETORS OF THE PROVINCE OF EAST NEW JERSEY, 1682-1684

\title{
BY JOSEPH R. KLETT
}

Joseph R. Klett, a graduate of Rutgers SCILS, is Chief of Archives in the Division of Archives

and Records Management, New Jersey Department of State.

The New Jersey State Archives' 2005 acquisition of the record book of East Jersey's proprietary governor, Robert Barclay, was an important development in the field of New Jersey history. That state representatives were authorized to attend and bid at a high-profile, public auction to secure archival material was unprecedented. The purchase, as well, of five unique maps extracted from the book and offered as separate auction lots made the state's success even more exciting and amplifies the importance of these materials for historical study.

The groundswell of public interest and political attention surrounding this purchase was noteworthy; it was covered in the press before and after the auction, at the unveiling of the documents, and in several articles that have since appeared in print and online. ${ }^{1}$ What has not been publicized before now are the significant ways in which the late Richard P. McCormick influenced the preliminary analysis and display of the Barclay records and maps.

It should surprise no one familiar with his life's work that Dr. McCormick was keenly interested in the content of the Barclay accession. After all, Christie's auction house advertised the record book and maps as containing unique information relating to the colonization of New Jersey. That alone was sure to pique the curiosity of Rutgers' legendary dean, who at eightyeight was as passionate as ever about the details of the state's history. The extent to which the Barclay records might shed new 
light on New Jersey's proprietary period, however, was not clear from their description prior to the sale. ${ }^{2}$ The auction catalog noted that the book contained copies of the East Jersey charters, as well as a register of the shareholders' minutes from June 1682 to March 1684. The auctioneers did not fully appreciate or advertise that this register predates the minutes of the East Jersey Proprietors in America, which commence April 9, 1685. ${ }^{3}$ These largely unstudied 1682-84 minutes, along with the maps (three of which are hand-drawn), make the Barclay record book one of the most valuable historical documents now preserved in the public archives of our state.

Following the State Archives' success at auction, Karl J. Niederer, Director of the New Jersey Division of Archives and Records Management, invited Dr. McCormick to join in the initial analysis of the acquisition. The venerable scholar gladly accepted the offer, and, to our elation, he agreed to speak at the public unveiling of the collection at Morven Museum and Gardens in Princeton in September 2005. Dr. McCormick's visit to study the documents prior to the event was in itself a truly memorable occasion for the State Archives staff. As he read the minutes we heard occasional exclamations of youthful glee: "Hah!" This meant he had come upon a fact of special note. By all accounts, Dr. McCormick's inspiring and endearing remarks at the September unveiling celebration were the highlight of the official ceremonies. [His remarks are recorded in Sewell's article in this volume.]

By coincidence, and to the good fortune of the historical community, Professor McCormick had another direct role in the preservation of New Jersey's colonial archives in the final year of his life. From 2003 to the fall of 2005, representatives of the State Archives and the West Jersey Council of Proprietors had discussed the terms and advantages of depositing the vast West Jersey archive with the state. Dr. McCormick acted in the interests of both the East Jersey Board of Proprietors (which dissolved in 1998) and the West Jersey Council, on behalf of the state university, and in his own best interests as a scholar/ historian. At the time the West Jersey deposit was proposed, 
Dr. McCormick announced his own support for the idea to his fellow Council members. It was clear from the start of negotiations that this personal endorsement was of utmost importance to the West Jersey officers. His advice to them and his participation in a special meeting of the proprietors in Burlington on 12 October 2005 to consider the proposed deposit agreement undoubtedly influenced its unanimous adoption by the Council later that morning.

In December 2005, the State Archives and the West Jersey Council jointly opened over 300 years of West Jersey deeds, surveys, maps and other provincial records to public research. It was yet another milestone for New Jersey history directly involving Richard P. McCormick. Sadly, his deteriorating health by then prevented him from participating in the celebration. He passed away a month later.

Given Dr. McCormick's lifelong dedication to public history and his fervent support of public records preservation and access, the compiler presents the transcription that follows as a humble offering to the memory of a great man. The staff of the State Archives were honored to cross paths with him in such historically significant ways in the months prior to his passing. The compiler expresses profound appreciation to Rutgers University Libraries for the opportunity to participate in this commemoration.

$* * *$

The register of proprietary minutes transcribed below comprises forty-five manuscript pages labeled as item number 56 in the Barclay record book. It documents nearly two years of activity of the East Jersey shareholders, from the Quaker acquisition of the province to their appointment of local governmental authority. Among other things, the minutes document the selection of Robert Barclay as governor, the development of the "Fundamentall [sic] Constitutions," and the negotiations with and instruction of Deputy Governor Gawen Laurie, who was chosen to administer the colony on behalf of the absentee governor. They tell of the planning and 
establishment of Perth Amboy as the new provincial capital, the construction of proprietary buildings, and the enticement of Scottish colonists. They note the proprietors' claim to Staten Island and order Laurie to demand the same for East Jersey. Certainly, the "new" minutes contain considerable data to be studied, collated, and compared with previously known facts.

The minutes also contain numerous references to the paper records of the proprietors. They announce the arrival and dispatch of communications with officials in Scotland and America. They order maps to be "fairly drawne" and charters to be engrossed on parchment. They recount the minutest details of William Dockwra's researches on behalf of the shareholders to procure title papers from the Carteret family, the Duke of York, and the ancient record offices of London. As an archivist, the compiler was thrilled by these glimpses into the history of proprietary manuscripts themselves. Moreover, he is gratified by his role in enabling scholarly analysis of this previously obscure historical source.

In the transcription that follows, spelling and capitalization are retained as they appear in the original manuscript. Superfluous punctuation and certain marks have been omitted. For example, the diacritical mark above the second " $c$ " in "Instruccon" (denoting that it is to be read like " $\mathrm{ti}$ ") and the overscoring of the " $\mathrm{m}$ " in "Sume" (marking it as a double letter) do not appear below. In the latter case, however, the second " $\mathrm{m}$ " will appear in the transcription to reflect the intention of the scribe. Occasionally, minor punctuation (a comma or period) has been added in order to retain intended context or to separate sentences.

Aside from the quirks of seventeenth-century orthography, the reader is cautioned that the minutes are rife with abbreviations and superscriptions-all of which are retained as originally penned. Only very few instances warranted notation, set off by italics in square brackets, to clarify the meaning of a word. Finally, the reader should note that references to poundsrendered " $\mathrm{lb}$ " or " $£$ " in modern usage-in the minutes typically takes the form of superscribed letters "li" (i.e., libra). 
Notes

1. See Joseph R. Klett, "An Account of East Jersey's Seven Settled Towns, circa 1684" in The Genealogical Magazine of New Jersey 80 (September 2005): 106-14; and Karl J. Niederer, "Ancient Documents Reopen New Jersey's Colonial History" in New Jersey Heritage Magazine 5 (Winter 2006): 56-58.

2. The compiler and Dr. Maxine N. Lurie have made a considerable effort to understand what, of the content of the record book, was readily available to scholars prior to 2005. Given the extent of the documents, and the fact that various iterations and partial copies of some texts have survived in archives and in print, the analysis and cross-checking are complex. Dr. Lurie recently discovered the following two citations to the Barclay record book, for which the State Archives is indebted, as they shed light on the provenance of the book. The first comes from Dunn et al.,, eds., The Papers of William Penn, Volume Two, 1680-1684 (Philadelphia: University of Pennsylvania Press, 1982), which published at least one Penn document from the Barclay record book, namely his 11 July 1683 letter to the Proprietors of East New Jersey on pp. 412-3. This source indicates that the record book was accessible through the Friends House Library, London, apparently as part of a deposit of Barclay of Bury Hill papers. The second reference-in Ned C. Landsman's Scotland and Its First American Colony, 1683-1765 (Princeton, NJ: Princeton University Press, 1985), 301-2, notes 13 and 14-reiterates that the book was, for a time, accessible at the Friends House Library.

3. The minute books and other official records of the East Jersey Proprietors in America are among the holdings of the State Archives, having been accessioned in 1998 after the corporate dissolution of the East Jersey Board and the sale of their land rights to the state. Their minutes from 1685 to 1794 were published, from 1949 to 1985 , by the General Board of Proprietors and the New Jersey Historical Society, 
beginning with The Minutes of the Board of Proprietors of the Eastern Division of New Jersey from 1685 to 1705, compiled by George J. Miller. 